\title{
PLASMA EXPANDER FOR VENETIAN BLIND DIRECT CONVERTERS
}

\author{
Richard R. Smith
}

April 6, 1973

Prepared for U.S. Atomic Energy Commission under contract No. W-7405-Eng-48
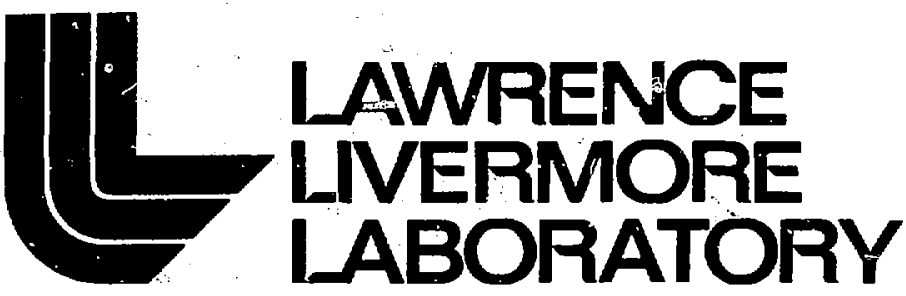

University of California/Livermore 
NOTICE

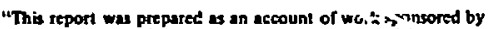
the United Stntes Coremment. Neither the United Sistes nor the United States Atomie Enery Commission, nor any of their employees, nor any of their contractors, subcontractions, or their employes, makes any wernnty, express or implied, of assimes any lepl lisbitity or xcapondbility for the accuracy, completeness of befulnes of any infocmution, apparatus, product or process diselosed, of represents that its use would not infringe privitely. owned rights."

- Frinted in the United States of America Available from

National Technical Information Service

U.S. Department of Commerce 5285 Port Royal Road

Springfield, Virginia 22151

Price: Printed Copy \$_* Microfiche $\$ 0.95$

NTIS

\begin{tabular}{c} 
* Pages \\
\hline $1-519$ \\
$51-150$ \\
$151-325$ \\
$326-500$ \\
$501-1.000$
\end{tabular}

Selling Price

$\$ 4.00$

$\$ 5.45$

$\$ 7.60$

$\$ 10.60$

$\$ 13.60$ 
TID-4500, UC-20

Controlled Thermonuclear Processez

\author{
노 \\ LAWAENCE INEFMORE LABORATORY

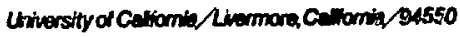

U ?RL- -51373

\title{
PLASMA EXPANDER FOR VENETIAN BLIND DIRECT CONVERTERS
}

Richard R, Smith

MS. date: April 6, 1973
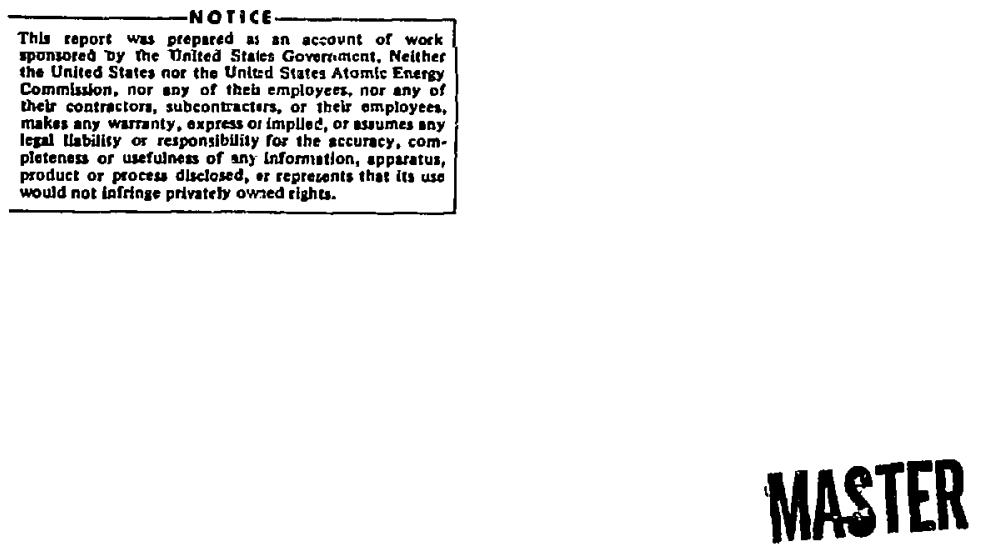

DISTRABLITON OF THIS DGCUREEMI IS UMLAMIED 


\section{Contents}

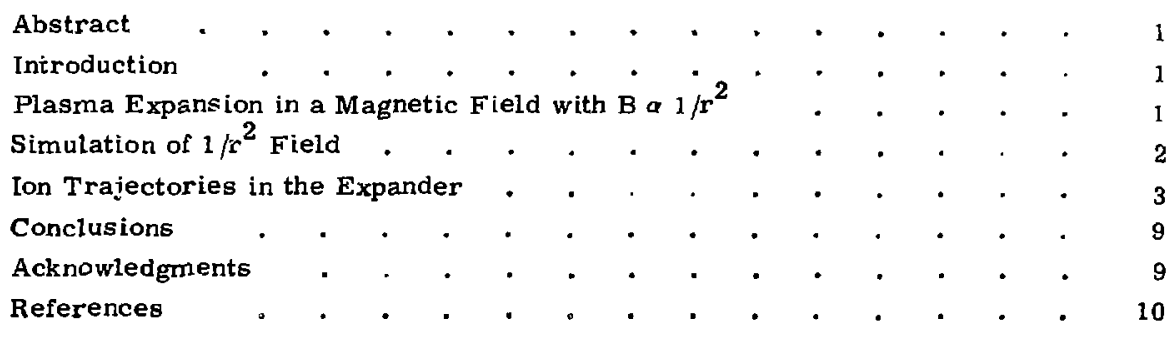




\title{
PLASMA EXPANDER FOR VENETIAN BLIND DIRECT CONVERTERS
}

\begin{abstract}
Characteristics and advantages of a plasma expander with a field simulating that of a Inagnetic monopole were investigated. Such a field, with $\mathrm{B} \alpha 1 / \mathrm{r}^{2}$, exactly cinserves an ion's magnetic

moment. The expander is especially suitable for a "Venetian Blind" direct recovery unit. A nonopole field can be approximated with coils arranged on the surface of a $30^{\circ}$ cone, except at the apex and base of the cone.

\section{Introduction}

Moir and Barr ${ }^{1}$ recently proposed a direct converter that differs from the one proposed by Post. ${ }^{2}$ This so-called "Venetian Blind" converter is intended to expand the plasma from the reactor in a field decreasing inversely as the square of the distance from the reactor (rather

than a field decreasing inversely as the distance), thus making a higher ratio of expansion possible over a shorter distance. The collector has a lower maximum theoretical efficiency but can handle muck higher space charge and thus operate at a substantially lower reactor temperature.
\end{abstract}

\section{Plasma Expansion in a Magnetic Fieid with $B \alpha 1 / r^{2}$}

In the expander designed for a Post-type converter, the field lines form a flat fan with an intensity decreasing as $1 / \mathrm{r}$ from the fan's vertex. It was found from computer simulations ${ }^{3}$ that one could define a parameter

$$
\epsilon=\left|\frac{2 \pi m V_{\|}}{q B} \frac{1}{B} \frac{d B}{d B}\right|
$$

that had to be less than 3 during the trajectory, to ensure a sufficiently constant magnetic moment. Guided by the experience with the fan-shaped expander, we anticipated that the $1 / \mathrm{r}^{2}$ sxpander would have problems towards the end of the trajectory, where $\epsilon$ would be proportional to $r$ and grow large.

It is possibie to rigorously prove the consiancy of the magnetic moment in a $1 / \mathrm{r}^{2}$ fielc! 4 In spherical coordinates the field is that of a monopole:

$$
\vec{B}=B_{0} r_{o}^{2} \frac{\overrightarrow{\mathbf{r}}}{r^{3}}
$$

From the equation of motion we get

$$
\overrightarrow{\dot{v}}=\dot{s}_{0}^{2} \Omega \frac{\vec{v} \times \vec{R}}{r^{3}} \text {. }
$$

where $\Omega$ is $\mathrm{qB}_{\mathrm{o}} / \mathrm{m}$. Ore finds that the angle $\theta$ between the position vector of the 
particle and the $Z$ axis is equal to $\tan ^{-1}$ $\left(\mathrm{V} / \mathrm{r}_{\mathrm{o}} \Omega\right)$; that $\mathrm{r}^{2}=\mathrm{r}_{\mathrm{o}}^{2}+\mathrm{V}^{2} \mathrm{t}^{2}$; and that $v_{\perp}=-r_{0} v / r$. From this it follows that the magnetic moment $\mu$, defined as $(\mathrm{m} / 2)\left(\mathrm{V}_{\perp}^{2} / \mathrm{B}\right)$, is constant.

Thus one must not be too zealous in applying a criterion for adiabaticity based on a simple gradient of the firld, such as (see: Ref. 5)

$$
\frac{v_{i}}{B} \frac{\partial B}{\partial z} \leq \frac{\Omega}{N},
$$

where $\Omega=z e B / N$ and $N$ is an empirical constant such as 20, because such a criterion

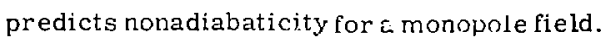

\section{Simulation of $1 / r^{2}$ Field}

Once the constancy of $\mu$ in a $1 / r^{2}$ field is zeen, it is of interest to examine the difficulty of realizing such a field with coils. An expander consisin. 5 of two cones was designed by using the MAFCO magnetic field code. ${ }^{6}$ The first cone was small and represented the neutron trap that expands the plasma from $150 \mathrm{kG}$ to about $50 \mathrm{kG}$. The second cone had a vertex half-angle of $15^{\circ}$ and constituted the bulk of the device. In this second cone the field lines were to seem to diverge from a common point. The currents in the circular loop constituting the cone of coils were chosen proportional to $1 /\left(z+z_{0}\right)^{2}$, where the cone axis is along $z$ and $z_{0}$ is the distance from the origin to the desired field line focus. The currents must be increased somewizat as one approaches the end of the expander.

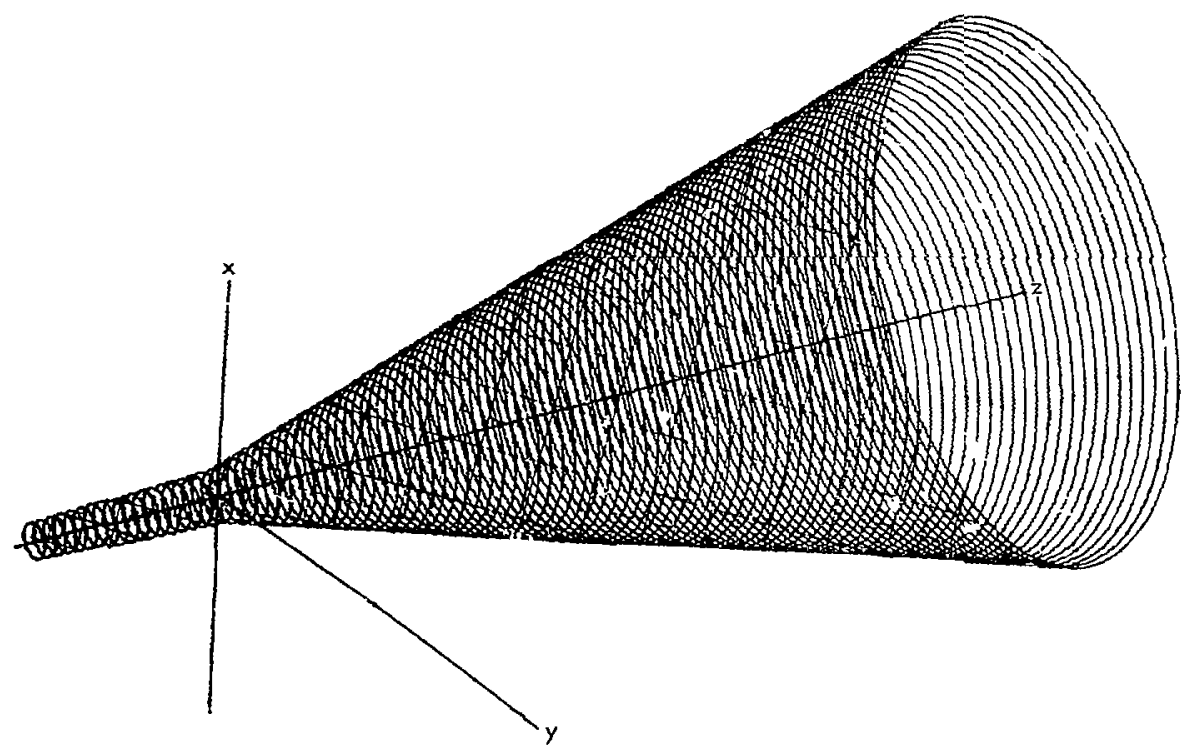

Fig. 1. Perspective view of coil configuration used in simulation of a Venetian Blind plasma expander. 
Figure 2 is a perspective drawing of the coil configuration. Figure 2 shows a $\mathrm{rl}$ ' of the field line parailicl to the cone and passing through $z=0, R=94 \mathrm{~cm}$. The field ine is nearly straight, out to the region of the collect:- elements at $z=$ $z=65 \mathrm{~m}$. This line enclosed the desired flux of $150 \mathrm{~Wb}$ and thus was the guiding center line farthest from the axis that had to be considered. The coily are spaced $1 \mathrm{~m}$ ap $\approx \mathrm{i} \mathrm{t}$, from $-18 \mathrm{~m}$ to $+80 \mathrm{~m}$. Table 1 shows 1 he coil location $z$, radius $A$ in centime."ers, and current $I$ in amperes. A 150-kG mir or coil is assumed to contríbute to the field.

Figure 3 shows the magnetic field contours in the $1 / r^{2}$ regisn. While it is not clear if the contours down to $200 \mathrm{G}$ are concentric circles as they would be in a $1 / \mathrm{r}^{2}$ f:eld, they are at least concave to the left. The bend in the field lines at $z=0$ is of no importance to the constancy of the magnetic moment, because the field strength is quite large there and the field variation in one pitch length is amall Thus we conclude inat it is rot difficult to simulate a $l / r^{2}$ field.

There is an additional advantage of a $1 / \mathrm{r}^{2}$ expander over a fan-shaped $1, \mathrm{r}$ device.

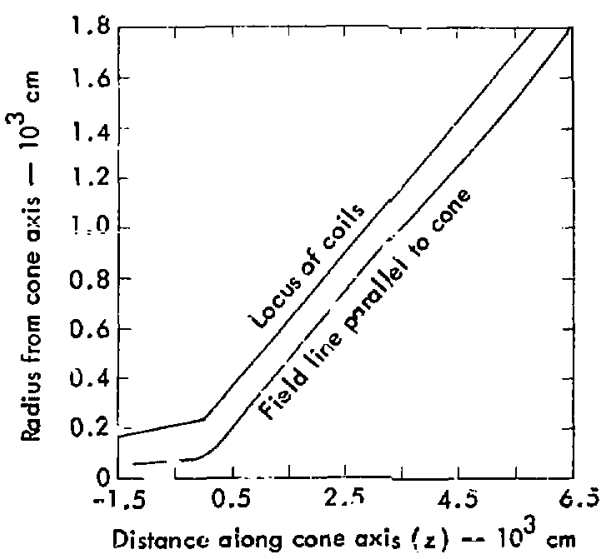

Fig. 2. Field line parallel to coils. Note scale disto-tion on this and succeeding figures.

In the latter case the fieid lines are spread much more in one direction than in the other. Th'18 the angle between the local field and the motion of the guiding center will vary periodically for the fan expander but not for the conical or monopole expander. Such a periodic modulation would not average to zero because of the changing field strength and gyrofrequency, and such "bumpiness" could affect the ion's perpendicular energy.

\section{Ion Trajectories in the Expander}

Having determined that the expander magnetic field simulates that of a monopole, the orbits of several representative ions were examined in detail. Figure 4 shows $\mu$ versus $\mathrm{t}$ for a $14.7-\mathrm{MeV}$ proton launched from $z=0$ with its guiding center on the limiting field line of Fig. 2. The magnetic moment dips at the end of the orbit because the ion is slipping off its bending field line, and the velocity happens to become nearly parallel to $\vec{B}$ for the particular choice of initial orit conditions. Such a proton launched on the limiting field line fits inside the expander walls.

Five $300-k e V$ tritons were launched at $\mathrm{z}=\mathbf{0}$ on the $\mathrm{z}$ axis on the four field lires shuwn in Fig. 5. These lines passed through $r=20,40,60$, and $80 \mathrm{~cm}$. The 


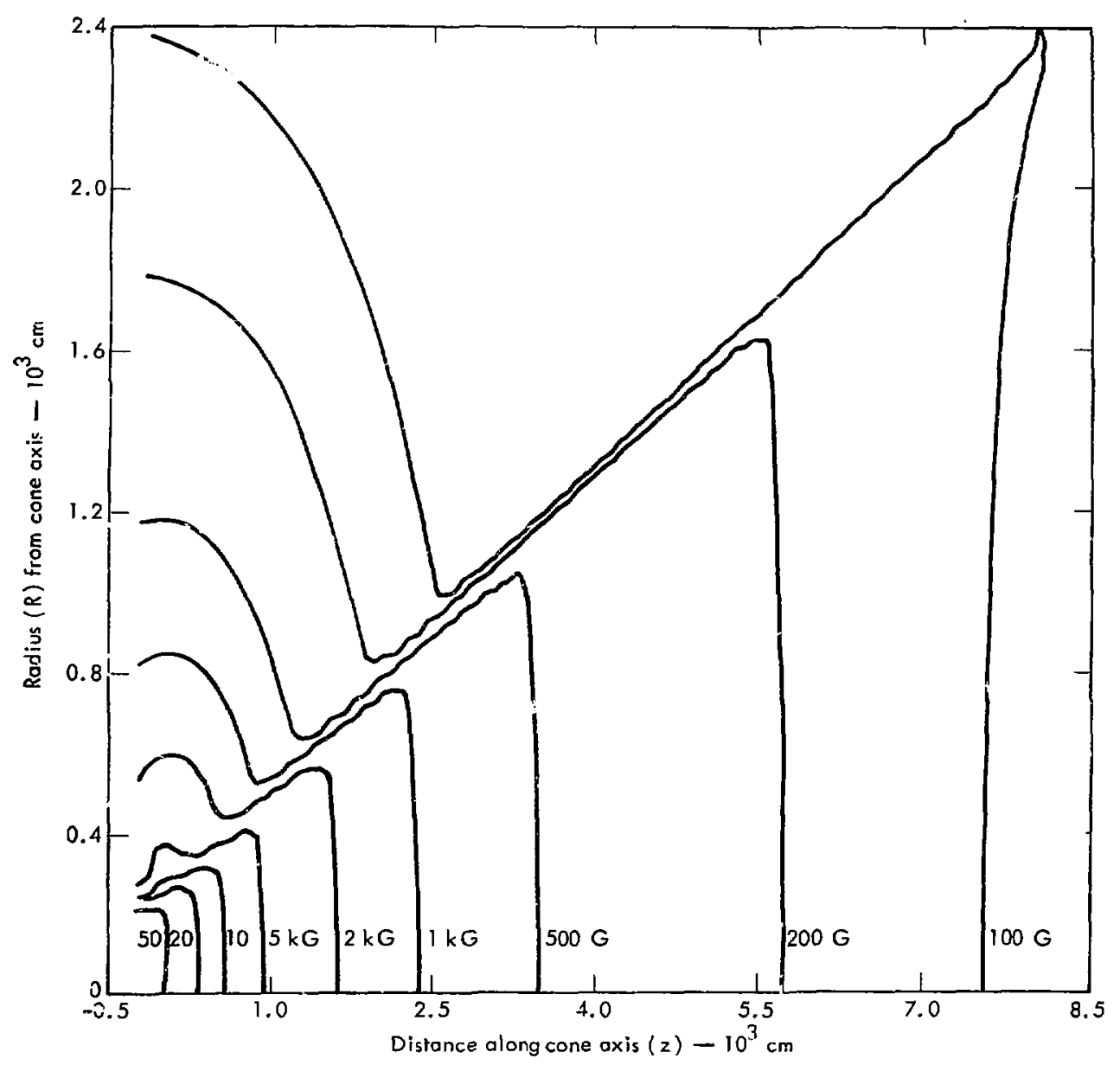

Fig. 3. Contour plot of magnetic field.

pitch length in the region of the collector structure, i.e., near $z=6500 \mathrm{~cm}$, exceeds $30 \mathrm{~m}$ and is too large for the orbits to follow the field lines at the end of the expander. This is shown in Fig. 6a, a projection of the orbit launched on the axis onto the vertical plane. The timedependence of the magnetic moment during this orbit is shown in Fig. 6b. An end-on view of this orbit is shown in Fig. 6c. Figures $7 a$ and $7 b$ show $x$ versus $z$ and $\mu$ versus $\mathrm{t}$ for the orbit launched at $\mathrm{z}=0$ $r=80 \mathrm{~cm}$. The magnetic moment of all five cases had acceptably small variations near the beginning of each orbit. The changes in $\mu$ at the ends of the orbits are due to the field lines bending. This effect is most pronounced for the trajectories 
Table 1. MAFCO input data.

\begin{tabular}{|c|c|c|c|c|c|c|}
\hline$x$ & $\mathrm{y}$ & $\begin{array}{l}\text { Coil } \\
\text { location } \\
\text { (z), cm }\end{array}$ & $\begin{array}{l}\text { Radius } \\
(\mathrm{A}), \mathrm{cm}\end{array}$ & Alpha & Beta & $\begin{array}{c}\text { Current } \\
\text { (I), A }\end{array}$ \\
\hline $\begin{array}{l}0 . \\
0 . \\
0 . \\
0 . \\
0 .\end{array}$ & $\begin{array}{l}0 . \\
0 . \\
0 . \\
0 . \\
0 .\end{array}$ & $\begin{array}{l}-1800.00 \\
-1700.00 \\
-1600.00 \\
-1500.00 \\
-1400.00\end{array}$ & $\begin{array}{l}152.00 \\
156.00 \\
161.00 \\
165.00 \\
169.00\end{array}$ & $\begin{array}{l}0 . \\
0 . \\
0 . \\
0 . \\
0 .\end{array}$ & $\begin{array}{l}0 . \\
0 . \\
0 . \\
0 . \\
0 .\end{array}$ & $\begin{array}{l}12800000.00 \\
12400000.00 \\
11800000.00 \\
11100000.00 \\
10700000.00\end{array}$ \\
\hline $\begin{array}{l}0 . \\
0 . \\
0 . \\
0 . \\
0 .\end{array}$ & $\begin{array}{l}0 . \\
0 . \\
0 . \\
0 . \\
0 .\end{array}$ & $\begin{array}{l}-1300.00 \\
-1200.00 \\
-1100.00 \\
-1000.00 \\
-900.00\end{array}$ & $\begin{array}{l}173.00 \\
178.00 \\
182.00 \\
186.00 \\
190.00\end{array}$ & $\begin{array}{l}0 . \\
0 . \\
0 . \\
0 . \\
0 .\end{array}$ & $\begin{array}{l}0 . \\
0 . \\
0 . \\
0 . \\
0 .\end{array}$ & $\begin{array}{r}10100000.00 \\
9880000.00 \\
9460000.00 \\
9040000.00 \\
8930000.00\end{array}$ \\
\hline $\begin{array}{l}0 . \\
0 . \\
0 . \\
0 . \\
0 .\end{array}$ & $\begin{array}{l}0 . \\
0 . \\
0 . \\
0 . \\
0 .\end{array}$ & $\begin{array}{l}-800.00 \\
-700.00 \\
-600.00 \\
-500.00 \\
-400.00\end{array}$ & $\begin{array}{l}195.00 \\
199.00 \\
203.00 \\
208.00 \\
212.00\end{array}$ & $\begin{array}{l}0 . \\
0 . \\
0 . \\
0 . \\
0 .\end{array}$ & $\begin{array}{l}0 . \\
0 . \\
0 . \\
0 . \\
0 .\end{array}$ & $\begin{array}{l}8260000.00 \\
7980000.00 \\
7560000.00 \\
7200000.00 \\
7150000.00\end{array}$ \\
\hline $\begin{array}{l}0 . \\
0 . \\
0 . \\
0 . \\
0 .\end{array}$ & $\begin{array}{l}0 . \\
0 . \\
0 . \\
0 . \\
0 .\end{array}$ & $\begin{array}{c}-300.00 \\
-200.00 \\
-100.00 \\
0.00 \\
100.00\end{array}$ & $\begin{array}{l}216.00 \\
220.00 \\
229.00 \\
229.00 \\
256.00\end{array}$ & $\begin{array}{l}0 . \\
0 . \\
0 . \\
0 . \\
0 .\end{array}$ & $\begin{array}{l}0 . \\
0 . \\
0 . \\
0 . \\
0 .\end{array}$ & $\begin{array}{l}7030000.00 \\
6450000.00 \\
5710000.00 \\
5280000.00 \\
2630000.00\end{array}$ \\
\hline $\begin{array}{l}0 . \\
0 . \\
0 . \\
0 . \\
0 .\end{array}$ & $\begin{array}{l}0 . \\
0 . \\
0 . \\
0 . \\
0 .\end{array}$ & $\begin{array}{l}200.00 \\
300.00 \\
400.00 \\
500.00 \\
600.00\end{array}$ & $\begin{array}{l}283.00 \\
310.00 \\
336.00 \\
363.00 \\
390.00\end{array}$ & $\begin{array}{l}0 . \\
0 . \\
0 . \\
0 . \\
0 .\end{array}$ & $\begin{array}{l}0 . \\
0 . \\
0 . \\
0 . \\
0 .\end{array}$ & $\begin{array}{r}1610000.00 \\
1090000.00 \\
823000.00 \\
646000.00 \\
520000.00\end{array}$ \\
\hline $\begin{array}{l}0 . \\
0 . \\
0 . \\
0 . \\
0 .\end{array}$ & $\begin{array}{l}0 . \\
0 . \\
0 . \\
0 . \\
0 .\end{array}$ & $\begin{array}{r}700.00 \\
800.00 \\
900.00 \\
1000.00 \\
1100.00\end{array}$ & $\begin{array}{l}417.00 \\
444.00 \\
470.00 \\
497.00 \\
524.00\end{array}$ & $\begin{array}{l}0 . \\
0 . \\
0 . \\
0 . \\
0 .\end{array}$ & $\begin{array}{l}0 . \\
0 . \\
0 . \\
0 . \\
0 .\end{array}$ & $\begin{array}{l}426000.00 \\
337000.00 \\
302000.00 \\
260000.00 \\
226000.00\end{array}$ \\
\hline $\begin{array}{l}0 . \\
0 . \\
0 . \\
0 . \\
0 .\end{array}$ & $\begin{array}{l}0 . \\
0 . \\
0 . \\
0 . \\
0 .\end{array}$ & $\begin{array}{l}1200.00 \\
1300.00 \\
1400.00 \\
1500.00 \\
1600.00\end{array}$ & $\begin{array}{l}551.00 \\
578.00 \\
604.00 \\
631.00 \\
658.00\end{array}$ & $\begin{array}{l}0 . \\
0 . \\
0 . \\
0 . \\
0 .\end{array}$ & $\begin{array}{l}0 . \\
0 . \\
0 . \\
0 . \\
0 .\end{array}$ & $\begin{array}{l}197000.00 \\
174000.00 \\
155000.00 \\
139000.00 \\
125000.00\end{array}$ \\
\hline $\begin{array}{l}0 . \\
i . \\
0 . \\
0 . \\
0 .\end{array}$ & $\begin{array}{l}0 . \\
0 . \\
0 . \\
0 . \\
0 .\end{array}$ & $\begin{array}{l}1700.00 \\
1800.00 \\
1900.00 \\
2000.00 \\
2100.00\end{array}$ & $\begin{array}{l}685.00 \\
712.00 \\
738.00 \\
765.00 \\
792.00\end{array}$ & $\begin{array}{l}0 . \\
0 . \\
0 . \\
0 . \\
0 .\end{array}$ & $\begin{array}{l}0 . \\
0 . \\
0 . \\
0 . \\
0 .\end{array}$ & $\begin{array}{r}113000.00 \\
103000.00 \\
94400.00 \\
86500.00 \\
76400.00\end{array}$ \\
\hline $\begin{array}{l}0 . \\
0 . \\
0 . \\
0 . \\
0 .\end{array}$ & $\begin{array}{l}0 . \\
0 . \\
0 . \\
0 . \\
0 .\end{array}$ & $\begin{array}{l}2200.00 \\
2300.00 \\
2400.00 \\
2500.00 \\
2600.00\end{array}$ & $\begin{array}{l}i 19.00 \\
846.00 \\
872.00 \\
899.00 \\
926.00\end{array}$ & $\begin{array}{l}0 . \\
0 . \\
0 . \\
0 . \\
0 .\end{array}$ & $\begin{array}{l}0 . \\
0 . \\
0 . \\
0 . \\
0 .\end{array}$ & $\begin{array}{l}73500.00 \\
66200.00 \\
63300.00 \\
58900.00 \\
55100.00\end{array}$ \\
\hline $\begin{array}{l}0 . \\
0 . \\
0 . \\
0 . \\
0 .\end{array}$ & $\begin{array}{l}0 . \\
0 . \\
0 . \\
0 . \\
0 .\end{array}$ & $\begin{array}{l}2700.00 \\
2800.00 \\
2900.00 \\
3000.00 \\
3100.00\end{array}$ & $\begin{array}{r}953.00 \\
98,00.00 \\
1006.00 \\
1033.00 \\
1060.00\end{array}$ & $\begin{array}{l}0 . \\
0 . \\
0 . \\
0 . \\
0 .\end{array}$ & $\begin{array}{l}0 . \\
0 . \\
0 . \\
0 . \\
0 .\end{array}$ & $\begin{array}{l}51500.00 \\
48100.00 \\
45300.00 \\
42200.00 \\
40500.00\end{array}$ \\
\hline
\end{tabular}


Table 1. (Cont inued).

\begin{tabular}{|c|c|c|c|c|c|c|}
\hline $\mathbf{x}$ & $\mathbf{y}$ & $\begin{array}{c}\text { Coil } \\
\text { location } \\
(\mathrm{z}), \mathrm{cm}\end{array}$ & $\begin{array}{l}\text { Radius } \\
\text { (A), cm }\end{array}$ & Alpha & Beta & $\begin{array}{c}\text { Current } \\
\text { (I), A }\end{array}$ \\
\hline $\begin{array}{l}0 . \\
0 . \\
0 . \\
0 . \\
0 .\end{array}$ & $\begin{array}{l}0 . \\
0 . \\
0 . \\
0 . \\
0 .\end{array}$ & $\begin{array}{l}3200.00 \\
3300.00 \\
3400.00 \\
3500.00 \\
3600.00\end{array}$ & $\begin{array}{l}1087.00 \\
1114.00 \\
1140.00 \\
1167.00 \\
1194.00\end{array}$ & $\begin{array}{l}0 . \\
0 . \\
0 . \\
0 . \\
0 .\end{array}$ & $\begin{array}{l}0 . \\
0 . \\
0 . \\
0 . \\
0 .\end{array}$ & $\begin{array}{l}39300.00 \\
38500.00 \\
36500.00 \\
34700.00 \\
32900.00\end{array}$ \\
\hline $\begin{array}{l}0 . \\
0 . \\
0 . \\
0 . \\
0 .\end{array}$ & $\begin{array}{l}0 . \\
0 . \\
0 . \\
0 . \\
0 .\end{array}$ & $\begin{array}{l}3700.00 \\
3800.00 \\
3900.00 \\
4000.00 \\
4100.00\end{array}$ & $\begin{array}{l}1221.00 \\
1248.00 \\
1274.00 \\
1301.00 \\
1328.00\end{array}$ & $\begin{array}{l}0 . \\
0 . \\
0 . \\
0 . \\
0 .\end{array}$ & $\begin{array}{l}0 . \\
0 . \\
0 . \\
0 . \\
0 .\end{array}$ & $\begin{array}{l}31400.00 \\
29900.00 \\
29200.00 \\
28500.00 \\
27000.00\end{array}$ \\
\hline $\begin{array}{l}0 . \\
0 . \\
0 . \\
0 . \\
0 .\end{array}$ & $\begin{array}{l}0 . \\
0 . \\
0 . \\
0 . \\
0 .\end{array}$ & $\begin{array}{l}4200.00 \\
4300.00 \\
4400.00 \\
4500.00 \\
4600.00\end{array}$ & $\begin{array}{l}1355.00 \\
1322.00 \\
1408.00 \\
1435.00 \\
1462.00\end{array}$ & $\begin{array}{l}0 . \\
0 . \\
0 . \\
0 . \\
0 .\end{array}$ & $\begin{array}{l}0 . \\
0 . \\
0 . \\
0 . \\
0 .\end{array}$ & $\begin{array}{l}25800.00 \\
24700.00 \\
23700.00 \\
23000.00 \\
22100.00\end{array}$ \\
\hline $\begin{array}{l}0 . \\
0 . \\
0 . \\
0 . \\
0 .\end{array}$ & $\begin{array}{l}0 . \\
0 . \\
0 . \\
0 . \\
0 .\end{array}$ & $\begin{array}{l}4700.00 \\
4800.00 \\
4900.00 \\
5000.00 \\
5100.00\end{array}$ & $\begin{array}{l}1484.00 \\
1516.00 \\
1542.00 \\
1569.00 \\
1596.00\end{array}$ & $\begin{array}{l}0 . \\
0 . \\
0 . \\
0 . \\
0 .\end{array}$ & $\begin{array}{l}0 . \\
0 . \\
0 . \\
0 . \\
0 .\end{array}$ & $\begin{array}{l}21500.00 \\
21000.00 \\
20200.00 \\
19500.00 \\
19000.00\end{array}$ \\
\hline $\begin{array}{l}0 . \\
0 . \\
0 . \\
0 . \\
0 .\end{array}$ & $\begin{array}{l}0 . \\
0 . \\
0 . \\
0 . \\
0 .\end{array}$ & $\begin{array}{l}5200.00 \\
5300.00 \\
5400.00 \\
5500.00 \\
5600.00\end{array}$ & $\begin{array}{l}1623.00 \\
1650.00 \\
1676.00 \\
1703.00 \\
1780.00\end{array}$ & $\begin{array}{l}0 . \\
0 . \\
0 . \\
0 . \\
0 .\end{array}$ & $\begin{array}{l}0 . \\
0 . \\
0 . \\
0 . \\
0 .\end{array}$ & $\begin{array}{l}18200.00 \\
17700.00 \\
17100.00 \\
16400.00 \\
16000.00\end{array}$ \\
\hline $\begin{array}{l}0 . \\
0 . \\
0 . \\
0 . \\
0 .\end{array}$ & $\begin{array}{l}0 . \\
0 . \\
0 . \\
0 . \\
0 .\end{array}$ & $\begin{array}{l}5700.00 \\
\mathbf{5 8 0 0 . 0 0} \\
\mathbf{5 9 0 0 . 0 0} \\
6000.00 \\
\mathbf{6 1 0 0 . 0 0}\end{array}$ & $\begin{array}{l}1757.00 \\
1784.00 \\
1310.00 \\
1837.00 \\
1864.00\end{array}$ & $\begin{array}{l}0 . \\
0 . \\
0 . \\
0 . \\
0 .\end{array}$ & $\begin{array}{l}0 . \\
0 . \\
0 . \\
0 . \\
0 .\end{array}$ & $\begin{array}{l}15400.00 \\
15200.00 \\
14600.00 \\
14400.00 \\
13900.00\end{array}$ \\
\hline $\begin{array}{l}0 . \\
0 . \\
0 . \\
0 . \\
0 .\end{array}$ & $\begin{array}{l}0 . \\
0 . \\
0 . \\
0 . \\
0 .\end{array}$ & $\begin{array}{l}6200.00 \\
6300.00 \\
6400.00 \\
6500.00 \\
6600.00\end{array}$ & $\begin{array}{l}1891.00 \\
1918.00 \\
1944.00 \\
1971.00 \\
1998.00\end{array}$ & $\begin{array}{l}0 . \\
0 . \\
0 . \\
0 . \\
0 .\end{array}$ & $\begin{array}{l}0 . \\
0 . \\
0 . \\
0 . \\
0 .\end{array}$ & $\begin{array}{l}13600.00 \\
13200.00 \\
13000.0 n \\
12700.00 \\
12300.00\end{array}$ \\
\hline $\begin{array}{l}0 . \\
0 . \\
0 . \\
0 . \\
0 .\end{array}$ & $\begin{array}{l}0 . \\
0 . \\
0 . \\
0 . \\
0 .\end{array}$ & $\begin{array}{l}6700.00 \\
6800.00 \\
6900.00 \\
7000.00 \\
7100.00\end{array}$ & $\begin{array}{l}2025.00 \\
2052.00 \\
2078.00 \\
2105.00 \\
2132.00\end{array}$ & $\begin{array}{l}0 . \\
0 . \\
0 . \\
0 . \\
0 .\end{array}$ & $\begin{array}{l}0 . \\
0 . \\
0 . \\
0 . \\
0 .\end{array}$ & $\begin{array}{l}12200.00 \\
12100.00 \\
11900.00 \\
11900.00 \\
11700.00\end{array}$ \\
\hline $\begin{array}{l}0 . \\
0 . \\
0 . \\
0 . \\
0 .\end{array}$ & $\begin{array}{l}0 . \\
0 . \\
0 . \\
0 . \\
0 .\end{array}$ & $\begin{array}{l}7200.00 \\
7300.00 \\
7400.00 \\
7500.00 \\
7600.00\end{array}$ & $\begin{array}{l}2159.00 \\
2186.00 \\
2212.00 \\
2239.00 \\
2266.00\end{array}$ & $\begin{array}{l}0 . \\
0 . \\
0 . \\
0 . \\
0 .\end{array}$ & $\begin{array}{l}0 . \\
0 . \\
0 . \\
0 . \\
0 .\end{array}$ & $\begin{array}{l}11700.00 \\
11500.00 \\
11200.00 \\
11100.00 \\
11000.00\end{array}$ \\
\hline $\begin{array}{l}0 . \\
0 . \\
0 . \\
0 .\end{array}$ & $\begin{array}{l}u . \\
0 . \\
0 . \\
0 .\end{array}$ & $\begin{array}{l}7700.00 \\
7800.00 \\
7900.00 \\
8000.00\end{array}$ & $\begin{array}{l}2293.00 \\
2320.00 \\
2346.00 \\
2373.00\end{array}$ & $\begin{array}{l}0 . \\
0 . \\
0 . \\
0 .\end{array}$ & $\begin{array}{l}0 . \\
0 . \\
0 . \\
0 .\end{array}$ & $\begin{array}{l}11500.00 \\
12100.00 \\
12200.00 \\
12300.00\end{array}$ \\
\hline
\end{tabular}




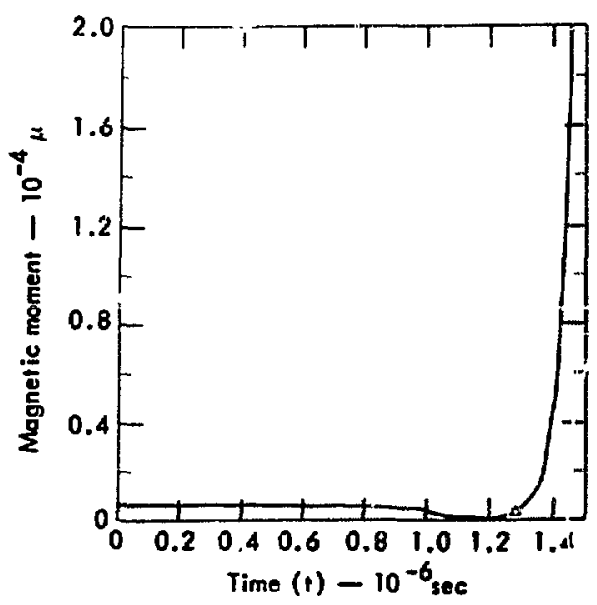

Fig. 4, Magnetic moment versus time for a 14.7-MieV proton, Encounter with collector structuze is at $\Delta(6500)$.

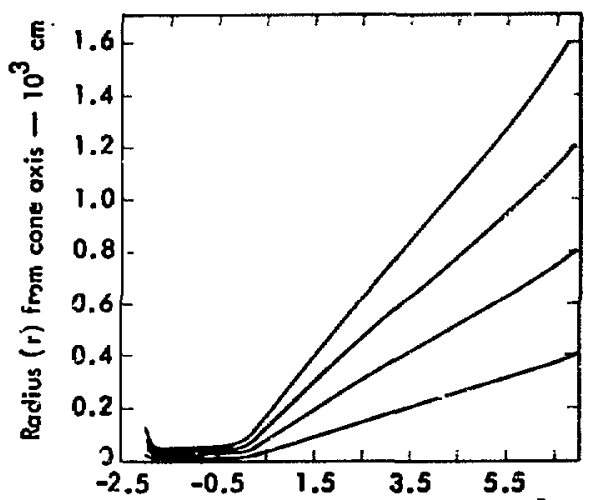

Distance along cone axis $(z)-10^{3} \mathrm{~cm}$

Fig. 5. Field lines passing through $\mathrm{z}=0, R=20,40,60$, and $80 \mathrm{~m}$.

neareat the colle. The approximate time at which the ion encounters the collector structure is indicated by $\Delta$ on Figs. 4, 6b, and $7 \mathrm{~b}$.

Table 2 summarizes the properties of these orbits at $z=6500 \mathrm{~cm}$ : $\theta_{1}$ is the

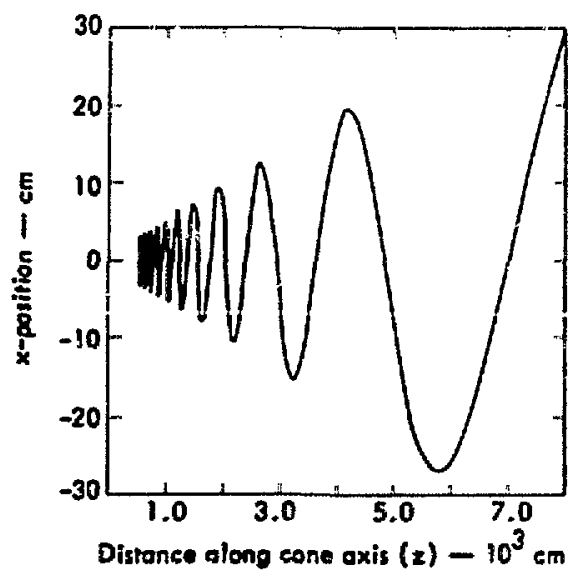

Fig. 6a. Orbit of a 300-key triton launched with guiding center on the 2 axls.

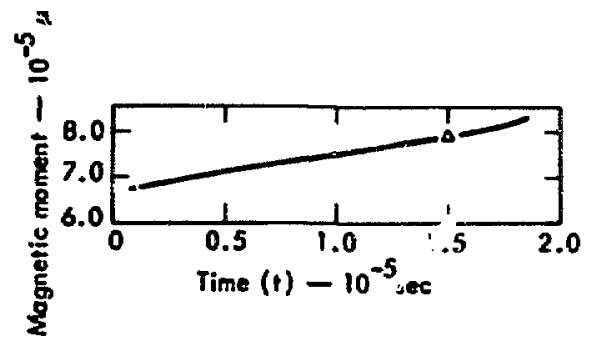

Fig. 6b. Magnetic moment versus time for orbit in Fig. Ga.

angle between the guiding center field line and the $z$ axis; $\theta_{2}$ is the same angle at $z=5500 \mathrm{~cm}$; and $\theta_{3}$ is the expected angle between the guiding center field line and the $z$ axis if the field lines had diverged from a common point and if the line passing through $z=0, r=94 \mathrm{~cm}$ has an angle of 15. The angle between $\vec{v}$ and the guiding line is $\phi_{1}$, and $\phi_{2}$ is that angle if the line had not started to bend. The $x, y$, and $z$ components of velocity are $u, v$, and $w$. From co: iparing $\theta_{1}$ and $\theta_{2}$ we see that the 


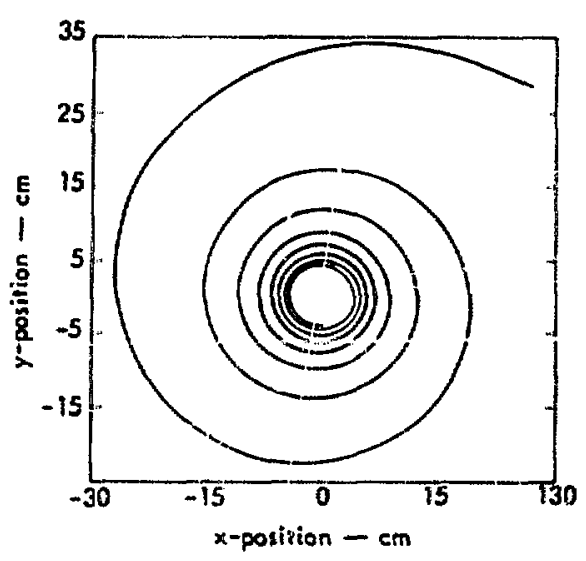

Fig. 6c. End-on view of orblt in Mig. 6a.

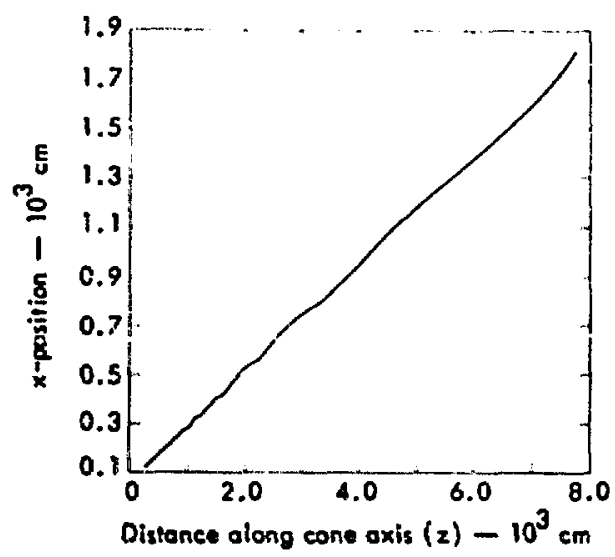

Fig. 7a. Orblt of a 300-keV triton leunched to follow a field line through $z=0, R=80 \mathrm{~cm}$.

rield lines behave as expested up to $z=5500$ and then stert to bend outwarde slightly. This could be corrected by conlinuing the windings past $z=80 \mathrm{~m}$ or by adjuating the coll currents. The angle $\phi_{2}$ is important in calculating the efficiercy of the Venetian Blind converter, because it gives the spread in entrance angle. For these orbits this spread is evidently bounded by $\pm 3^{\circ}= \pm 0,05$ radians. From lig. 4 in Ref. 2, this should not be a severe problem.

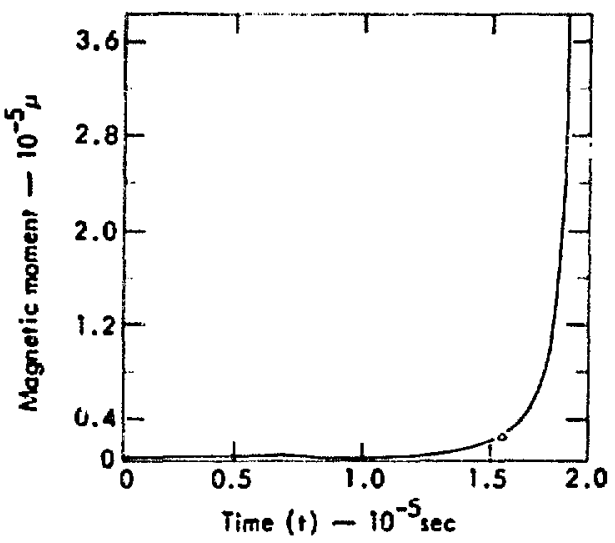

Fig. 7b. Magnetic moment versus time for orbil in Fig. 7 a.

Table 2. Parameters of five orbits.

\begin{tabular}{|c|c|c|c|c|c|c|c|c|}
\hline Orbit & $\begin{array}{c}\theta_{1} \\
\text { deg }\end{array}$ & $\begin{array}{c}\theta_{2} \\
d_{e}\end{array}$ & $\begin{array}{r}\theta_{3} \\
\text { deg }\end{array}$ & $\begin{array}{l}\phi_{1} \\
\text { deg }\end{array}$ & $\begin{array}{l}\phi_{2} \\
\text { deg }\end{array}$ & $\begin{array}{c}U_{1} \\
\mathrm{~cm} / \mathrm{sec}\end{array}$ & $\frac{v}{\mathrm{~cm} / \mathrm{sec}}$ & $\underset{\mathrm{cm} / \mathrm{sec}}{\mathrm{W}}$ \\
\hline 1 & 0 & 0 & 0 & 2,1 & 2.1 & $0.118 \times 10^{8}$ & $0.097 \times 10^{8}$ & $4.375 \times 10^{8}$ \\
\hline 2 & 3.6 & 3.5 & 3.3 & 1.6 & 2.5 & 0.354 & 0.134 & 4.361 \\
\hline 3 & 7.8 & 6.3 & 6.5 & 2.8 & 2.7 & 0.582 & 0.182 & 4.335 \\
\hline 4 & 11.2 & 9.5 & 9.7 & 3.0 & 3.1 & 0.779 & 0.220 & 4.302 \\
\hline 5 & 14.8 & 12.8 & 12.8 & 4.0 & 2.9 & 0.946 & 0.215 & 4.269 \\
\hline
\end{tabular}




\section{Conclusions}

We have seen that there are two advantages of expanding a plasma in a $1 / r^{2}$ field rather than in a $1 / \mathbf{r}$ fan-shaped field: more expansion per unit length and better preservation of magnetic moment, as a result of the straightness of the field lines. It is relatively easy to approximate the field of a magnetic monopole throughout most of a conical expander with a full angle of $30^{\circ}$ at the apex. When magnetic fields, dimensions, and ion trajectories appropriate to a Venetian Blind direct energy recovery unit (Ref. 4) are used, the computed orbits are close to those desired.

\section{Acknowledgments}

The author wishes to thank W. L. Barr and $\mathbf{R}$. W. Moir for helpful discussions and encouragement, and Barsy Howard and Tom Haratani for their help in the computations. 


\section{References}

1. R. W. Moir and W. L. Barr, "Venetian Blind' Direct Energy Converter for Fusion Reactors," Nucl. Fusion 13, 35 (1973).

2. R. F. Post, "Mirror Systems: Fuel Cycles, Loss Reduction and Energy Recovery," in Proc. International Conference on Nuclear Fusion Reactors, Culham Laboratory, Sept. 17-19, 1969, pp. 88-111.

3. R. W. Moir and J. D. Lee, Criteria for Design of an Adiabatic Expander for a Direct Energy Converter, Lawrence Livermore Laboratory Rept. UCRL-51351 (1973).

4. P. C. Clemmow and J. P. Dougherty, Electrodynamics of Particles and Plasmas (Addison-Wesley, Reading, Mass., 1969), pp. 90-99.

5. J. H. Foote, "Non-Adiabatic Energy Limit vs. Mirror Ratio in a Magnetic Well Geometry," Plasma Phys. 14, 543 (1972).

6. W. A. Perkins and J. C. Brown, "MAFCO - A Magnetic Field Code for Handling General Current Elements in Three Dimensions," J. Appl. Phys. 35, 3337 (1964). 